\title{
Introduction
}

\section{Vladimir Popov}

There is no shortage of predictions that the twenty-first century will see the bridging of the gap between the rich (the West) and the poor countries (the Rest), and especially predictions of the rise of Asia, notably two Asian giants - China and India. The goal of this book is to analyse factors behind the recent rise of many developing countries, to try to predict changes that may result from the continuation of this trend and plot possible scenarios of future development. It is argued that the 'rise of the Rest' would not only imply geopolitical shifts (the rise of Asia) but could lead to the proliferation of the new growth models in the Global South (à la East Asian dirigisme) and profound changes in the international economic relations (new world economic order).

Many growth promoting instruments that are now regarded as unfair are likely to gain legitimacy: industrial policies, including protectionism and undervaluation of the exchange rate ('exchange rate protectionism') to promote growth; freer transfer of technology from North to South, including the weakening of the protection of intellectual property rights; restriction on foreign direct investment (FDI) (such as requirements to ensure exports and technology transfer); restrictions on short-term capital flows to reduce volatility; barriers to brain drain from the South, but freer international migration regime for low skilled workers; increase in development assistance and creation of new international financial institutions to manage aid of the West to the South; creation of international stabilization funds for resource commodities; adoption of preferential environmental, labor, safety and other standards for developing countries (proportional caps on emissions, for instance, are unfair to the South, where per capita emissions are much lower than in the West).

New rules of international relations may explicitly limit the use of force only to cases of severe violations of non-political rights (that is, mass repressions, hunger, ethnic violence and so on) and prohibit the use of force against liberal authoritarian regimes (just for the sake of 'establishing democracy'). There is likely to be a reform of the United Nations (UN) institutions, including the Security Council, and greater respect for the 
prohibition of unilateral military interventions (without the consent of the UN). There are also certainly going to be 'surprise' changes in the world economy and international relations that we cannot predict today.

The chapters of this book examine the factors behind the 'rise of the Rest', discuss how robust these trends are, speculate about implications and consequences, and analyse possible scenarios.

Chapter 1 (Vladimir Popov, Jomo Kwame Sundaram) examines the trajectory of growth in the Global South. Before the 1500s all countries were roughly at the same level of development, but from the 1500s Western countries started to grow faster than the rest of the world and gross domestic product (GDP) per capita (purchasing power parity (PPP) based) by 1950 in the USA, the richest Western nation, was nearly five times higher than the world average. Since 1950 this ratio has stabilized - not only have Western Europe and Japan improved their relative standing in per capita income versus the USA but East Asia, South Asia and some developing countries in other regions have also started to bridge the gap with the West. After nearly half a millennium of growing economic divergence, the world seems to have entered the era of convergence. The factors behind these trends are analysed and scenarios and implications for the future considered.

Chapter 2 (Sahan Savas Karatasli, Sefika Kumral, Daniel Pasciuti and Beverly J. Silver) seeks to understand the significance of contemporary radical changes in world income distribution (most notably the recent rapid rise of China, India and a handful of other peripheral countries) by comparing the present with other periods of world-hegemonic transition. The empirical core of the chapter examines the interrelationship between the rise and decline of world hegemonies and changes in the global stratification of wealth (between-country inequality) from the sixteenth century to the present. It is found that (like the contemporary period) past periods of world-hegemonic crisis and transition have been characterized by radical transformations in the global hierarchy of wealth, although there are fundamental differences in the nature/direction of change in each transition. The chapter draws on world-systems theories of global inequality and hegemonic cycles to conduct a comparative-historical analysis of the dynamics underlying the long-term empirical patterning in the global distribution of wealth and power. The authors analyse the implications of their findings for the ongoing debate about whether we are in the midst of an impending 'great convergence' or on the verge of a major reversal of fortunes favoring the global North/West.

Chapter 3 (Vladimir Popov) argues that the single most important factor determining growth rates is institutions and that state capacity depends on the trajectories of institutional development. There are two 
major groups of developing countries: one (East and South Asia, Middle East and North Africa (MENA)) has relatively low inequalities, strong state institutions (low murder rate and share of shadow economy) and high savings and investment rate; the other (Latin America, sub-Saharan Africa, Russia and some former Soviet republics) has high inequalities, weak state institutions (high murder rate and shadow economy) and low savings and investment rate. Quite predictably the first group grows faster than the second. Shadow economy and murder rates are regarded as objective measures of institutional capacity of the state and it is shown that economic growth rates are strongly correlated with these objective measures. The greatest threat to the ongoing 'rise of the Rest' is the increase in income inequalities within countries from the 1980s. The continuation of this trend could result in social upheavals. As large masses of the population become disadvantaged due to increased inequalities, there may also be a rise of nationalism as rightist political groups blame all the disasters and misfortunes on globalization. This may lead to conflicts, if not wars, between countries, with collapse of international trade and capital flows, like in the 1930s. The world may go once again over the familiar twentieth-century historical track and there may be a pause in or even a reversal of globalization, as during the Great Depression when the outburst of protectionism led to the decline of the international trade and capital movements.

Chapter 4 (Justin Yifu Lin) examines what are the good policies for engineering an economic miracle. For a developing country to use the advantage of backwardness is to follow the comparative advantage determined by its own factor endowment in the industrial upgrading and technological innovation in a market economy with a facilitating state, as practiced in the East Asian economies and elaborated in the new structural economics. Regrettably, under the drive of nation building and the influence of prevailing structuralism, the governments in most developing countries adopted an import-substitution strategy in an attempt to defy their comparative advantages and jump directly to develop the advanced industries prevailing in the West. To implement the strategy, their governments have introduced all kinds of interventions and distortions to protect/subsidize the non-viable firms in the priority industries. Their economies became uncompetitive, growth unsustainable and crises hit frequently. Instead of advantage, the backwardness becomes disadvantage in achieving rapid, sustained growth. On the contrary, China and the East Asian economies have been lucky in not following the inappropriate prevailing thinking in their development and transition policies due to the constraints of poor resources and the inherent pragmatism in their culture. Their success reveals the nature and causes of a developing country's attempt to catch up 
with the West. The new structural economics intends to theorize the East Asian economies' successes and the failures of the 'Rest.'

Chapter 5 (Luiz Carlos Bresser-Pereira) argues that the 'Rest' will only be able to catch up and grow more than the West if it goes against a 'received truth': capital-rich countries should transfer their capitals to capital-poor countries. This is the mantra that the West uses to occupy the markets of developing countries with their finance and their multinationals. Yet, New Developmentalism tells us that developing countries will invest (and save) more if their current account is balanced, if not showing a surplus. Starting from a balanced current account, the decision to incur deficits or grow cum 'foreign savings' - actually, foreign finance - will appreciate the exchange rate in the long term and discourage investment. In consequence, we will have a high rate of substitution of foreign for domestic savings, and foreign funds will finance consumption, not investment. Yet, developing countries have difficulty in realizing this, first, because the West and their economists are adamant in recommending current account deficits; second, because such a policy is consistent with high preference for immediate consumption; and, third, because economists in developing countries are unable to criticize the 'growth cum foreign savings policy.'

Chapter 6 (Jayati Ghosh) explores the conditions in international trade needed for countries wishing to industrialize and complete their development project. Essentially, when countries are open to external trade in a world in which increasing returns activities are significant, the chances are greater that such trade will cement existing divisions of labor between countries because those countries with small or infant industries will be unable to compete with the competition from larger or more advanced industries elsewhere. When these trade patterns get disrupted, either through conscious commercial policies in some countries or because of other factors (such as wars, global recessions and so on) there are greater chances of some countries breaking out of the existing division of labor to diversify into higher value added increasing returns activities. So 'instability' in global trade can indeed generate possibilities for industrialization under certain conditions - though it should be noted that the implications vary greatly depending upon the domestic economic conditions and policies adopted by such countries.

Chapter 7 (Prabhat Patnaik) looks at the recent seemingly successful development in India and argues that high growth has been accompanied by such an increase in economic inequality and such a process of 'social retrogression' that the country faces the real threat of social disintegration. The neoliberal regime, even while it increases economic and social inequality, creates a constituency for itself which additionally has a vested interest in perpetuating the inequities of the social order. Neoliberal capitalism, in 
other words, far from dealing destructive blows on the old social order as commonly expected actually plays the role of strengthening the inequities of the old social order, of worsening its fault lines. Capitalism in 'newly emerging societies,' in other words, does not just arrest the democratic revolution, in a world conjuncture, which facilitates a rapid growth and consolidation of capitalism, it tends actually to roll back the democratic revolution. Hence, advancing the democratic revolution, and even retaining the democratic gains already made, requires, in societies like India, a resistance against the capitalism that marks the current conjuncture, that is, 'neoliberal capitalism.'

Chapter 8 (José Antonio Ocampo) explores three essential features of the economic history of Latin America. The first is that it was the part of the developing world (together with the Caribbean) most deeply transformed by colonization, as well as the first to become politically independent in the early nineteenth century (with the exception of Cuba). The second, which it shares with other parts of the developing world, has been its position within the world's economic system as a commodity producer, a feature that, a few countries aside, it has been unable to overcome despite the industrialization drive that took place in particular from the 1930 s to the 1970s. This has made the region vulnerable to trends and fluctuations in commodity prices. This vulnerability, which has been enhanced in different periods by highly unstable and pro-cyclical access to external financing, has given rise to severe crises when these two factors have coincided. The third is that it is, together with parts of sub-Saharan Africa, the most unequal region of the world.

Chapter 9 (Richard Sakwa) looks at the two models in Europe that have been in contestation since the end of the Cold War - Wider Europe and Greater Europe. The tension between the two is a central facet of the cold peace that has predominated for the last quarter century, and has colored Russia's relations with the European Union (EU). Wider Europe is based on the tried and tested model of the EU, whose arc of good governance, economic liberalism and societal welfare was projected ever further to the East. The Greater European project sought finally to end the division of the continent, respecting the various cultural and civilizational traditions yet united on the principles of free trade, visa-free travel and the assertion of a multipolar but united continent in world affairs as a moderating force. This 'Gaullist' vision of continental Europeanism envisaged building on the already existing 'variable geometry' of European integration (notably the Council of Europe and the Organization for Security and Co-operation in Europe (OSCE)) to create a genuinely multipolar and pluralist vision of continental unity. Instead, the Wider European project was increasingly subsumed into a rampant Atlanticism and forced the countries in between 
the EU and Russia to choose between the two. The result was the Ukraine conflict and the new division of Europe.

Chapter 10 (Samir Amin) argues that among the 'Rest' only China is implementing a national project of modern industrial development in connection with the renovation of family agriculture. But outside China the other so-called emergent countries of the South (Brazil, Russia, India and China - BRIC) still walk only on one leg: they are opposed to the depredations of militarized globalization, but remain imprisoned in the straightjacket of neoliberalism. It is suggested to move away, as much as possible, from the 'liberal' recipe and the electoral masquerade associated with it and to set up a brand of new state capitalism with a social dimension (social, not socialist). That system would open the road to eventual advances toward a socialization of the management of the economy and therefore authentic new advances toward an invention of democracy responding to the challenges of a modern economy.

Finally, in the Conclusions (Piotr Dutkiewicz) there is an attempt to summarize different views presented in the chapters of the book and to plot the main scenarios of future developments of the world system and international economic relations. It is argued that the book advances three main sets of arguments. The first group of arguments based on evidence from three macro regions is focused on reasons for a successful/unsuccessful economic convergence (see chapters by Popov and Sundaram, Popov, Lin, Ghosh, Ocampo). The second major argument - related to state-market relations in the Rest - proposes that a 'new developmentalism' should go beyond the reductionist approach of two dominating economic schools structural (where the state rules) and neoliberal (where the unconstrained market dominates) toward a blend of both in a so-called 'dual track approach' to secure accelerated growth (see chapters by Popov, Lin, Bresser-Pereira). The third group of arguments advances ideas on policy measures and processes to improve 'well-being of the Rest' (see chapters by Popov, Lin, Patnaik, Ocampo, Sakwa, Amin). 